Laporan Kasus

\title{
Hipernatremia dan Infeksi pada Geriatri
}

\author{
Rizka Rosalinda1 ${ }^{1}$ Rose Dinda Martini²
}

\begin{abstract}
Abstrak
Hipernatremia merupakan gangguan elektrolit yang sering dijumpai pada pasien geriatri. Hipernatremia berhubungan erat dengan morbiditas dan mortalitas. Bermacam faktor dapat menyebabkan hipernatremia pada geriatri seperti perubahan ransangan haus, berkurangnya kemampuan pemekatan urin dan berkurangnya total body water. Penatalaksanaan hipernatremia membutuhkan rehidrasi cairan dan mencari penyebab hipernatremia agar tidak berulang kembali. Telah dilaporkan suatu kasus pada perempuan 83 tahun dengan keluhan penurunan kesadaran. Pada pemeriksaan fisik ditemukan kesadaran somnolen dan turgor kulit menurun. Pemeriksaan laboratorium didapatkan natrium serum $172 \mathrm{mmol} / \mathrm{L}$, dan osmolalitas serum 393mOsm/L. Tatalaksana awal pasien diberikan terapi rehidrasi dengan cairan hipotonis disertai monitoring elektrolit serum. Tatalaksana farmakologis dari penyulit seperti infeksi dan tatalaksana non farmakologis juga dilakukan. Follow up setelah terapi menunjukkan kesadaran pasien meningkat menjadi apati dengan kadar natrium 140mmol/L.
\end{abstract}

Kata kunci: hipernatremia, geriatri

\begin{abstract}
Hypernatremia is an electrolyte disorder that often found in geriatric patients. Hypernatremia is associated with significant morbidity and mortality. Various factors can cause hypernatremia in geriatrics such as changes in thirst stimulation, reduced urine concentration ability, and reduced total body water. Management of hypernatremia requires rehydration of the fluid and the underlying cause of hypernatremia to prevent the recurrence. This is a case report in geriatric women, eightythree years old with chief complaints of decreased consciousness. On physical examination we found somnolence and decreased skin turgor. Laboratory tests revealed serum sodium of onehundred seventytwo $\mathrm{mmol} / \mathrm{L}$, and serum osmolality of $393 \mathrm{mOsm} / \mathrm{L}$. Initial management of patients is given rehydration therapy with hypotonic fluid and serum electrolyte monitoring. Pharmacological management of complications such as infection and non-pharmacological management is also carried out. Follow-up after therapy showed that consciousness increased to apathy with sodium levels of $140 \mathrm{mmol} / \mathrm{L}$.
\end{abstract}

Keywords: hypernatremia, geriatrics

Affiliasi penulis: 1. Program Pendidikan Dokter Spesialis-1 IImu Penyakit Dalam FK Unand, 2. Subbagian Geriatri Bagian IImu Penyakit Dalam FK Unand/RSUP M Djamil Padang.

Korespondensi: pibipd@yahoo.com, rizka_r@yahoo.com Telp: 0751-37771

\section{PENDAHULUAN}

Indonesia termasuk lima besar negara dengan jumlah penduduk usia lanjut terbanyak di dunia, yaitu mencapai 18,1 juta jiwa atau 7,6 persen dari total penduduk. Jumlah penduduk usia lanjut (diatas 60 tahun) diperkirakan akan meningkat menjadi 27,1 juta jiwa pada tahun $2020 .^{1}$
Masalah yang sering dijumpai pada pasien usia lanjut adalah sindroma geriatri. Sindroma geriatri merupakan kumpulan gejala dan atau tanda klinis, dari satu atau lebih penyakit, yang sering dijumpai pada pasien geriatri yang perlu penatalaksanaan segera dan dilakukan identifikasi penyebab. Sindroma geriatri terdiri dari malnutrisi, imobilisasi, instabilitas, infeksi, inkontinensia, insomnia dan lainnya. ${ }^{2}$

Malnutrisi merupakan gangguan nutrisi yang mempengaruhi tubuh secara klinis dan fungsional yang sering terjadi pada geriatri. Malnutrisi dihubungkan dengan kejadian buruk pada pasien 
geriatri karena dapat meningkatkan morbiditas, mortalitas, perpanjangan masa rawat di rumah sakit, keterlambatan pemulihan pasca rawat, meningkatnya komplikasi yang mengancam, gangguan fungsi, kualitas hidup yang buruk, meningkatnya infeksi, terjadinya gangguan elektrolit, anemia, dan keletihan. ${ }^{3}$

Faktor risiko malnutrisi pada usia lanjut meliputi kemiskinan, isolasi sosial, penyakit kronis dan akut yang diderita, polifarmasi, selera makan rendah, gangguan gigi geligi, disfagia, gangguan fungsi pada indera penciuman dan pengecap, pernapasan, saluran cerna, neurologi, infeksi, dan cacat fisik. Faktor lain seperti kurangnya pengetahuan mengenai asupan makanan yang baik, rasa kesepian dari keluarga juga menentukan status gizi usia lanjut. Faktor psikologis seperti depresi, kecemasan, demensia memiliki dampak dalam terjadinya malnutrisi. ${ }^{4}$

Gangguan elektrolit merupakan salah satu risiko yang sering terjadi pada geriatri yang malnutrisi, diantaranya hipernatremia. Hipernatremia terjadi $2 \%$ pada pasien geriatri yang masuk ke rumah sakit dan 5\%nya berusia lebih 75 tahun. Mortalitas hipernatremia yang dirawat di rumah sakit sekitar $33 \%$ dibandingkan dengan geriatri tanpa hipernatremia sebesar $15 \% .^{5}$

Hipernatremia adalah suatu keadaan dimana kadar natrium dalam darah lebih dari $145 \mathrm{mEq} / \mathrm{L}$. Hipernatremia pada geriatri sering disebabkan oleh kombinasi dari berkurangnya asupan cairan yang tidak adekuat dan bertambahnya kehilangan cairan. Penyebab hipernatremia diantaranya asupan makanan yang tidak mencukupi, meningkatnya kehilangan cairan karena diare, demam, atau muntah atau disebabkan secara iatrogenik seperti terapi diuretik. $^{5}$

Fisiologi tubuh terhadap hipernatremia adalah respon haus dan respon haus ini semakin berkurang seiring usia yang semakin lanjut. Disamping itu kemampuan ginjal untuk melakukan pemekatan urin yang semakin berkurang. Pasien geriatri dengan hipernatremia tidak hanya dikarenakan penurunan rasa haus dan gangguan kemampaun pemekatan urin tetapi seringkali disertai dengan gangguan akses mendapatkan cairan. 5,6
Gejala hipernatremia pada geriatri sering kali asimptomatik dimana rasa haus tidak sering ditemukan. Tanda hipernatremia dapat diperoleh dari turgor kulit yang menurun, mulut kering dan perubahan kesadaran. Perubahan kesadaran berasal dari gangguan sistem saraf pusat karena sel otak yang mengkerut (shrinkage) dengan munculan seperti bingung, hiperrefleks, kejang dan koma. Penurunan kesadaran merupakan prediktor kuat mortalitas pada geriatri. ${ }^{7}$

Koreksi hipernatremia dilakukan dengan meningkatkan asupan cairan, biasanya melalui cairan intravena. Direkomendasikan koreksi hipernatremia secara terus menerus tidak kurang dari 48 jam dengan kecepatan tidak lebih $12 \mathrm{mEq} / \mathrm{l} / \mathrm{hari}$. Penyebab dasar hipernatremia perlu dicari untuk mencegah hipernatremia berulang. ${ }^{7,8}$

Infeksi saluran kemih merupakan penyebab kesakitan akibat infeksi yang tertinggi setelah pneumonia pada geriatri. Gejala dan tanda ISK pada penderita geriatri sering sulit dikenali sehingga pengobatannya sering terlambat. Pengobatan yang terlambat memiliki dampak buruk pada pasien geriatri,seperti menurunnya status fungsional bahkan sampai kematian. ${ }^{9}$

Gejala klinis infeksi saluran kemih pada geriatri seperti disuria dan polakisuria, demam, nyeri tekan daerah suprapubis maupun sakit pinggang jarang ditemukan. Hal ini disebabkan oleh kemampuan ekspresi penderita geriatri berbeda dari penderita dewasa. Pasien geriatri biasanya telah memiliki gangguan faal kognitif. 9

Penatalaksanaan infeksi saluran kemih pada pasien geriatri terdiri atas dua ranah modalitas yakni yang nonfarmakologik dan farmakologik. Terapi farmakologik inisial dianjurkan secara empiris disesuaikan dengan pola kuman yang ada di setiap tempat. Golongan beta-laktam dan sefalosporin masih cukup efektif. Golongan kuinolon juga merupakan terapi pilihan empiris infeksi saluran kemih yang bisa diberikan. Lama pengobatan infeksi saluran kemih minimal tujuh hari. Pada geriatri dengan keadaan yang lebih berat atau dengan penyulit sebaiknya diberikan 
selama 14 hari. Penderita geriatri laki-laki secara umum mendapat terapi antibiotik selama 14 hari. ${ }^{9}$

Program nutrisi yang adekuat juga merupakan bagian dari terapi yang tidak terpisahkan. Tahap demi tahap asupan makanan dan cairan yang menuju optimal harus dikerjakan sesuai kemampuan penderita. 9

\section{KASUS}

Seorang pasien perempuan 83 tahun datang dengan keluhan penurunan kesadaran yang disadari keluarga sejak 4 hari sebelum masuk rumah sakit. Pasien awalnya dikatakan terlihat mulai banyak mengantuk dan kontak bicara yang semakin lama semakin sedikit dalam 2 minggu terakhir. Keluarga mengeluhkan pasien yang semakin mudah lupa dalam waktu 2 bulan ini yang dirasakan semakin memberat. Nafsu makan pasien dirasakan semakin menurun dalam 1 bulan terakhir dimana pasien hanya mampu menghabiskan makanan sebanyak 2-3 sendok makan saja. Demam dirasakan sejak 4 hari ini.

Pada riwayat pengobatan sebelumnya diketahui pasien pasca rawat 2 minggu yang lalu di RSUD dengan infeksi pneumonia dan keluhan tidak mau makan. Pasien telah diizinkan pulang tetapi pasca rawatan pasien tidak dapat melakukan aktivitas mandiri seperti biasanya. Pasien tidak diketahui memiliki riwayat penyakit dahulu yang berarti seperti hipertensi, diabetes, ataupun riwayat jatuh sebelumnya. Pasien tidak diketahui mengkonsumsi obat-obatan seperti diuretik sebelumnya. Saat ini pasien hidup seorang diri dirumah karena suami telah meninggal sedangkan anak-anaknya telah berkeluarga, hanya anak bungsu yang tinggalnya tidak jauh dari rumah pasien. Penghasilan pasien berasal dari pensiunan suami dan pemberian anaknya.

Pasien kemudian dirawat di bangsal bagian penyakit dalam RSUP dr M. Djamil Padang. Pada pemeriksaan fisik ditemukan kesadaran somnolen, tampak sakit sedang, takikadi 105x/menit dan suhu $37,9^{\circ} \mathrm{C}$ sedangkan tanda vital lainnya normal. Pada pasien ditemukan turgor kulit menurun, konjungtiva anemis, berat badan kurang (underweight) dengan Body Mass index 15,5. Pemeriksaan fisik yang lain dalam batas normal.
Pada pasien dilakukan Geriatric Comprehensive Assesment (CGA) dan didapatkan ADL Barthel saat ini ketergantungan total, Mini Nutritional Assesment (MNA) 10 atau dalam status malnutrisi. Penilaian penapisan depresi sukar dinilai serta penilaian Mini Mental Stage Examination (MMSE) sukar dinilai karena pasien penurunan kesadaran.

Hasil dari pemeriksaan laboratorium didapatkan hemoglobin $9.5 \mathrm{gr} / \mathrm{dl}$, leukosit 10.100/mm3, trombosit 147.000/mm3, hitung jenis leukosit 0/0/4/85/9/2, gambaran darah tepi ditemukan gambaran anemia normositik normokrom. Didapatkan kadar natrium serum $172 \mathrm{mmol} / \mathrm{L}$, kalium serum $3,7 \mathrm{mmol} / \mathrm{L}$, gula darah sewaktu $168 \mathrm{mg} / \mathrm{dl}$. Pemeriksaan fungsi ginjal dengan ureum $113 \mathrm{mg} / \mathrm{dl}$ dan creatinin 1,2mg/dl. Penghitungan osmolaritas serum 393mOsm/kg serta albumin serum 1,9gr/dl. Pemeriksaan urinalisa ditemukan leukosit 100-120/LPB.

Pasien memiliki permasalahan geriatri seperti hipernatremia, infeksi saluran kemih, anemia ringan, malnutrisi, imobilisasi.

Tatalaksana pada pasien ini diberikan berupa rehidrasi dengan cairan hipotonis 1/2NS untuk mengatasi hipernatremia dan dehidrasi. Cairan diberikan sebanyak 2-2,5L dengan diuresis sebanyak 1,5L. Monitoring serial elektrolit juga dilakukan. Pada hari ke 2 kadar natrium serum turun menjadi $158 \mathrm{mmol} / \mathrm{L}$ dan hari ke 4 stabil dengan nilai $140 \mathrm{mmol} / \mathrm{L}$.

Untuk mengatasi infeksi diberikan terapi empiris berupa antibiotik dan terapi suportif seperti pemasangan kasur dekubitus, perlakuan miring kanan dan miring kiri. Asupan makanan pasien diberikan dengan diet sebanyak $1225 \mathrm{kkal}$ berupa MC nabati $6 \times 100 \mathrm{cc}$ yang dinaikkan bertahap tergantung toleransi.

\section{PEMBAHASAN}

Telah dirawat pasien perempuan usia 83 tahun dengan hipernatremia et causa dehidrasi et causa low intake, sindroma geriatri (malnutrisi, infeksi saluran kemih). Diagnosis ini ditegakkan berdasarkan anamnesis, pemeriksaan fisik, laboratorium dan pemeriksaan penunjang lainnya. 
Malnutrisi merupakan awal geriatric giant yang melatarbelakangi terjadinya dehidrasi dan gangguan elektrolit pada pasien. Malnutrisi dan penurunan berat badan berkontribusi terhadap berkurangnya aktivitas fisik dan kesehatan, perubahan status kognitif, serta meningkatnya mortalitas. ${ }^{3}$

Faktor risiko terjadinya malnutrisi pada pasien ini adalah selera makan rendah, infeksi, kurangnya pengetahuan mengenai asupan makanan yang baik bagi usia lanjut, kesepian karena tinggal sendiri dan kemiskinan. Status nutrisi pasien buruk ditentukan dari BMI yang rendah dan kadar serum albumin rendah. ${ }^{4}$

Menua menyebabkan perubahan pada komposisi tubuh, fungsi organ dan kemampuan makan atau mengakses makanan pada usia lanjut. Malnutrisi berhubungan erat dengan status kesehatan yang buruk, morbiditas dan mortalitas yang meningkat, panjangnya masa rawatan rumah sakit, kualitas hidup yang buruk, gangguan elektrolit, meningkatnya infeksi, serta anemia. 4,5

Dehidrasi adalah berkurangnya cairan tubuh total dapat berupa hilangnya air lebih banyak dari natrium disebut dehidrasi hipertonik atau hilangnya air dan natrium dalam jumlah yang sama disebut dehidrasi isotonik atau hilangnya natrium yang lebih banyak dari pada air disebut dehidrasi hipotonik. Pada pasien ini terjadi dehidrasi hipertonik ditandai dengan tingginya kadar natrium serum $(>145 \mathrm{mEq} / \mathrm{L})$ dan peningkatan osmolalitas efektif serum (>285 mosmol/liter). ${ }^{9}$

Gejala dan tanda klinis dehidrasi pada usia lanjut sering tak jelas, samar-samar bahkan bisa tidak ada sama sekali. Apabila pasien ditemukan dengan aksila lembab, suhu tubuh meningkat dari suhu basal, diuresis berkurang, berat jenis urin lebih atau sama 1,019 serta rasio blood urea nitrogen $>16,9$ tanpa ada perdarahan aktif saluran cerna maka terdapat kemungkinan dehidrasi pada usia lanjut sebesar $81 \%$ selama diketahui pasien usia lanjut tersebut tidak memakai sitostatik, tidak ada perdarahan saluran cerna dan tidak ada kondisi overload. ${ }^{10}$

Hipernatremia pada pasien geriatri merupakan hal yang sering dijumpai dan berhubungan dengan morbiditas dan mortalitas. Usia lanjut merupakan predisposisi terjadinya hipernatremia karena proses menua seperti hilangnya rasa haus, gangguan pemekatan urin dan berkurangnya Total Body Water (TBW). Hipernatremia pada usia lanjut sering disebabkan oleh kombinasi dari asupan cairan yang tidak adekuat dan bertambahnya kehilangan cairan. Pasien dengan demensia mudah mengalami hipernatremia karena penurunan ransangan rasa haus dan gangguan kemampuan untuk meminta air. ${ }^{6}$

Penatalaksanaan segera pada pasien hipernatremia penting karena dapat mencegah keterlambatan diagnosa dan manajemen yang dapat menyebabkan mortalitas. Langkah pertama adalah analis klinis seperti berat badan, asupan makanan, output cairan dan analisis nutrisi. Status klinis yang juga penting adalah status volume dan pemeriksaan neurologi. Pengukuran osmolaritas plasma/urin dilakukan pada kasus yang lebih sulit. ${ }^{6}$

Koreksi hipernatremia harus dilakukan berhatihati karena adaptasi dari sel saraf pusat yang mengkerut dan koreksi yang terlalu cepat dapat menyebabkan edema serebral. Hipernatremia kronik diterapi secara perlahan dan hati-hati. Koreksi cairan dilakukan $50 \%$ dari kekurangan cairan dalam 12-24 jam pertama dari perhitungan. Kehilangan cairan yang berlangsung harus diidentifikasi dan cairan yang hilang harus diganti. Pada hipernatremia kronis direkomendasikan koreksi dilakukan 2 sampai 3 hari dengan koreksi maksimum natrium serum $0.5 \mathrm{mEq} / \mathrm{L} / \mathrm{hr}$ atau penurunan natrium serum 10 sampai $12 \mathrm{mEq} / \mathrm{L}$ dalam 24 jam. Koreksi yang terlalu cepat berhubungan dengan risiko edema serebral tetapi koreksi yang terlalu lama menyebabkan hipernatremia persisten. Pada hipernatremia kronis kekurangan air dikoreksi secara pelan sedangkan pada hipernatremia akut dikoreksi lebih cepat. 7,8

Menghitung kekurangan cairan dilakukan dengan menghitung Total Body Water (TBW) dalam liter dan dimasukkan kedalam formula: ${ }^{10}$

Water deficit $=\underline{(\text { plasma sodium }-140)} \times$ TBW 140

Pada pasien dehidrasi digunakan cairan hipotonik daripada normal isotonik karena cairan hipotonis akan mengkoreksi status volume dan natrium dalam waktu yang lebih cepat. ${ }^{10}$ 
Langkah terakhir adalah menentukan penyebab terjadinya hipernatremia, karena bila penyebab tidak diketahui maka pasien dapat kembali jatuh pada keadaan hipernatremia. ${ }^{10}$

Infeksi saluran kemih merupakan penyulit pada kasus ini. Infeksi saluran kemih merupakan salah satu permasalahan sindrom geriatri yang turut memperberat dehidrasi. Menurut Soejono (2005) perempuan usia lanjut mempunyai risiko lebih tinggi daripada laki-laki untuk menderita ISK dan mereka dengan status gizi kurang memiliki risiko ISK sebanyak 8-12 kali lebih tinggi dibandingkan mereka dengan status gizi normal. Gangguan faal kognitif yang terjadi pada pasien sebelum sakit juga merupakan predisposisi karena akan mengakibatkan usaha perawatan diri sendiri terganggu. ${ }^{9}$

Gejala infeksi saluran kemih tidak selalu ditemukan tetapi perlu dingat bahwa menurunnya nafsu makan hampir selalu menjadi gejala awal berbagai jenis infeksi pada penderita geriatri termasuk ISK. Penurunan nafsu makan pada geriatri terkadang dianggap sebagai sesuatu hal yang biasa sehingga terkadang diabaikan keluarga. Perlunya diwaspadai perubahan nafsu makan pada geriatri karena tidak saja berperan sebagai tanda awal penyakit, namun juga merupakan kondisi yang menurunkan status gizi dan kekebalan tubuh. Jika keadaan dibiarkan maka usia lanjut semakin lemah dan akan menurunkan status fungsionalnya. ${ }^{9}$

Terapi farmakologis secara empiris diberikan untuk mengatasi infeksi saluran kemih dan memperlihatkan perbaikan pada klinis dan laboratoris. Antibiotik diberikan sesuai dengan hasil kultur urin ditemukan E.coli >200.000 yang sensitif cefoperazon

Terapi non farmakologis perlu dilakukan pada pasien ini diantaranya mencegah imobilisasi lama pada pasien bed positioning, perubahan posisi secara teratur setiap 2-3 jam, melakukan latihan gerakan pasif minimal 2 kali sehari selama 20 menit, menggunakan kasur berongga (kasur antidekubitus), memiringkan pasien ke kanan dan ke kiri, mencegah terjadinya gesekan dan pemberian minyak setelah mandi dan mengompol.

Penatalaksanaan nutrisi pada pasien ini kita berikan secara oral. Diet diberikan 1200 kkal berupa makan cair yang kemudian secara bertahap dinaikkan tergantung toleransi pasien. Awalnya pasien selalu mencret setiap pemberian susu sehingga diet diganti dengan susu pan enteral dan mencret tidak ada lagi.

Penatalaksanaan pasien geriatri perlu dilakukan secara paripurna yang dikenal sebagai comprehensive geriatric asessment sehingga pasien berusia lanjut memiliki derjat kesehatan optimal dan kemampuan fungsional tertinggi. Penatalaksaan paripurna harus diberikan pada pasien ini karena menderita multimorbiditas, berupa mengatasi penyakit dasar dan penyerta serta sindroma geriatri yang ada. Edukasi pada keluarga sangat penting mengenai asupan nutrisi, kebersihan tubuh dan lingkungan, serta dukungan kasih sayang. Pada pasien ini penting dilakukan penilaian CGS secara berkala untuk menilai kemampuan fungsional pasien. Status nutrisi pasien yang malnutrisi akan dinilai secara berkala melalui MNA, begitu pula dengan ADL Barthel, penapisan depresi dan MMSE sampai mencapai derjat kesehatan optimal. ${ }^{9}$

\section{SIMPULAN}

Mengelola pasien geriatri dilakukan secara holistik dengan menggunakan Comprehensive Geriatric Asessment. Manajemen dilakukan tidak hanya mengobati penyakit dasar tetapi juga mencari penyebab seperti adanya penyakit kronis, adanya perasaan depresi dan isolasi sosial, maupun pemakaian obat-obatan. Dilaporkan suatu kasus pada lanjut usia seorang perempuan 83 tahun dengan hipernatremia disertai penyulit infeksi dan malnutrisi. Terapi berupa penggantian cairan memberikan hasil yang baik disamping terapi suportif mengatasi infeksi yang menyertai geriatri dan gizi untuk meningkatkan status nutrisi.

\section{DAFTAR PUSTAKA}

1. Kementerian kesehatan RI. Situasi Lanjut Usia di Indonesia. Infodatin Pusat Data dan Informasi Kementerian Kesehatan RI. 2016.

2. Setiati S. Geriatric medicine, sarkopenia, frailty dan kualitas hidup pasien usia lanjut: tantangan masa depan pendidikan, penelitian dan pelayanan kedokteran di Indonesia. eJKI. 2013;3:234-42. 
3. Saka B, Kaya O, Ozturk GB, Erten N, Karan MA. Malnutrition in the elderly and its relationship with other geriatric syndromes. Clinical Nutrition. 2010;29:745-8.

4. Alzahrani SA, Alamri SH. Prevalence of malnutrition and associated factors among hospitalized elderly patients in King Abdulaziz University Hospital, Jeddah, Saudi Arabia. BMC Geriatrics. 2017;17(1):136.

5. Muis SF, Purohita N. Gizi pada Lansia. Dalam: Martono H, Pramarka K, editor (penyunting). Geriatri (ilmu kesehatan usia lanjut). Edisi ke-4. Jakarta: Balai Penerbit FKUI. 2010.hlm.642.

6. Shah MK, Workeneh B, Taffe GE. Hypernatremia in the geriatric population. Clinical Interventions in Aging. 2014:9:1987-92.

7. Soiza R, Hoyle GE, Chua MP. Electrolyte and salt disturbances in older people: causes, management and implications. Reviews in Clinical Gerontology. 2008;18:143 -58.

8. Kugler JP, Husted T. Hyponatremia and hypernatremia in the elderly. Am Fam Physician. 2000;61(12):3623-30.

9. Soejono $\mathrm{CH}$. Infeksi saluran kemih pada geriatri. Majalah Kedokteran Indonesia. 2005;55:165-8.

10. Nur S, Khan Y, Nur S, Boroujerdi $H$. Hypernatremia: correction rate and hemodialysis. Journal of Hindawi. Case Reports in Medicine. $2014 ; 14: 1-4$ 